\title{
ANALISIS PENGARUH CURRENT RATIO (CR), COLLATERALIZABLE ASSETS (COL), RETURN ON EQUITY (ROE), DAN GROWTH TERHADAP DIVIDEND PAYOUT RATIO (DPR) \\ (Studi Empiris pada Perusahaan Manufaktur yang Terdaftar di BEI Periode 2005 - 2011)
}

\author{
Gretty Brigitta Liwe \\ (email: gretty_liwe@yahoo.com)
}

\begin{abstract}
Dividend policy is a policy of the company to be aware and careful consideration. In the dividend policy determined amount of profit allocation that can be distributed to shareholders (dividends) and the allocation of retained profits to the company. The greater the retained earnings, the smaller the dividend to be distributed to the shareholders. In the allocation of income arises various problems encountered. Announcement of the distribution of dividends by a company is a signal to shareholders.

This study aims to determine the effect of the Current Ratio (CR), Collateralizable Asset (COL), Return on Equity (ROE) and the Growth of the Dividend Payout Ratio (DPR) Studies on the Indonesia Stock Exchange Period 2005-2011.

The population in this study is the Company's Financial Statements listed on the Stock Exchange the share dividend. The samples are 8 companies during 2005 - 2011. The research instrument used secondary data and processed using SPSS 20, with the method of analysis used is multiple linear regression analysis.

Results of statistical research concludes that the Current Ratio, Collateralizable Assets, Return on Equity, and Growth together no significant effect on Dividend Payout Ratio on manufacturing companies in Indonesia Stock Exchange, also partially, Current Ratio, Collateralizable Assets, Return on equity, and Growth no significant effect on Dividend Payout Ratio on manufacturing companies in Indonesia Stock Exchange. The suggestion of this study is to further research, this study only uses the sample derived from a manufacturing company that can not necessarily be generalized to other industries. This is due to the limited time of the study. It is recommended in future studies could be expanded scope of research-type kejenis other industries also added the study variables such as Debt to Equity Ratio (DER), Return on Equity (ROE), and the ratio - the ratio of the other. And also expected in future studies to add a longer time span.
\end{abstract}

Key Words: Current Ratio, Collateralizable Asset, Return On Equity, Growth, Dividend Payout Ratio.

\section{PENDAHULUAN}

Kebijakan deviden merupakan salah satu kebijakan dalam perusahaan yang harus diperhatikan dan dipertimbangkan secara seksama. Dalam kebijakan deviden ditentukan jumlah alokasi laba yang dapat dibagikan kepada para pemegang saham (deviden) dan alokasi laba yang dapat ditahan perusahaan. Semakin besar laba yang ditahan, semakin kecil kebijakan membagikan deviden kepada para pemegang saham.

Pengumuman pembagian deviden oleh suatu perusahaan merupakan signal bagi pemegang saham. Pada dasarnya antara manajer dengan pemegang saham memiliki informasi yang berbeda, di mana manajer lebih memiliki informasi yang lengkap daripada pemegang saham.

Berdasarkan pernyataan tersebut dapat diketahui bahwa investor menginginkan kebijakan deviden yang stabil. Namun kenyataanya, rata-rata perkembangan Dividend Payout Ratio selama periode 2005-2009 mengalami fluktuasi. Berikut akan ditunjukkan perkembangan Dividend Payout Ratio pada perusahaan manufaktur yang membagikan deviden secara berturut-turut pada periode2005-2009. 
Tabel 1. Perkembangan Rata-Rata Dividend Payout Ratio Periode 2005-2009

\begin{tabular}{|l|l|r|r|r|r|r|}
\hline \multirow{2}{*}{ NO NamaPerusahaan } & \multicolumn{5}{|c|}{ DPR } \\
\cline { 3 - 7 } & & 2005 & 2006 & 2007 & 2008 & \multicolumn{1}{c|}{2009} \\
\hline 1. & PT. Fast Food Indonesia, Tbk & 21.61 & 12.95 & 19.58 & 20.31 & 20.35 \\
\hline 2. & PT. Multi Bintang Indonesia Tbk. & 76.64 & 75.60 & 89.89 & 142.17 & 22.59 \\
\hline 3. & PT. Gudang Garam,Tbk & 50.91 & 47.73 & 33.32 & 35.81 & 36.19 \\
\hline 4. & PT. Colorpak Indonesia, Tbk & 14.80 & 19.97 & 31.39 & 30.47 & 29.93 \\
\hline 5. & PT. SumiIndo Kabel Tbk & 27.06 & 24.14 & 39.50 & 39.16 & 14.92 \\
\hline 6. & PT. Metrodata Electronics Tbk & 37.19 & 29.19 & 21.42 & 6.79 & 20.21 \\
\hline 7. & PT. Tunas Ridean Tbk & 18.57 & 33.29 & 40.42 & 95.63 & 7.19 \\
\hline 8. & PT. United Tractor Tbk & 29.82 & 26.05 & 28.65 & 27.51 & 28.76 \\
\hline \multicolumn{2}{|c|}{ Rata-rata } & 34,58 & 33,62 & 38,02 & 49,73 & 22,52 \\
\hline
\end{tabular}

Sumber:ICMDdanIDX2005-2009

Berdasarkan tabel $1.1 \mathrm{di}$ atas dapat diketahui bahwa tingkat perkembangan rata-rata Dividend Payout Ratio (DPR) perusahaan manufaktur di Bursa Efek Indonesia (BEI) selama periode 2005-2009 mengalami fluktuasi. Dari sisi investor, deviden merupakan salah satu penyebab timbulnya motivasi investor menanamkan dananya dipasar modal. Dan karena informasi yang dimiliki investor di pasar modal sangat terbatas, maka perubahan devidenlah yang akan dijadikan sebagai sinyal untuk mengetahui performance perusahaan.

Dari fenomena dan teori yang diungkapkan di atas maka peneliti tertarik untuk melakukan penelitian tentang deviden. Penelitian ini membatasi penelitian terhadap factor yang mempengaruhi Dividend Payout Ratio (DPR), yaitu Current Ratio (CR), Collateralizable Assets (COL), Return On Equity (ROE) dan Growth. Selanjutnya penelitian ini diberi judul dengan judul: "ANALISIS PENGARUH CURRENT RATIO (CR), COLLATERALIZABLE ASSETS (COL), RETURN ON EQUITY (ROE), DAN GROWTH TERHADAP DIVIDEND PAYOUT RATIO (DPR).

Berdasarkan uraian sebelumnya, terdapat fenomena empiris yaitu adanya ketidaksesuaian antara teori dengan data empiris yang ditemukan dari variabel dependen pada setiap periodenya dan perlu diteliti lebih lanjut faktor-faktor apa saja yang mempengaruhi fenomena tersebut. Dari uraian tersebut di atas dapat dirumuskan masalah penelitian sebagai berikut:

1. Bagaimana pengaruh Current Ratio (CR) terhadap Dividend Payout Ratio?

2. Bagaimana pengaruh Collateralizable Assets (COL) terhadap Dividend Payout Ratio (DPR)?

3. Bagaimana pengaruh Return on Equity (ROE) terhadap Dividend Payout Ratio (DPR)?

4. Bagaimana pengaruh Growth terhadap Dividend Payout Ratio (DPR)?

\section{TINJAUAN PUSTAKA}

\section{LandasanTeori}

Kebijakan deviden (dividend policy) adalah keputusan apakah laba yang diperoleh perusahaan akan dibagikan kepada pemegang saham sebagai deviden atau akan ditahan dalam bentuk laba ditahan guna pembiayaan investasi dimasa datang. Apabila perusahaan memilih untuk membagikan laba sebagai deviden, maka akan mengurangi laba yang ditahan dan selanjutnya akan mengurangi total sumber dana intern atau internal financing (Sartono,2001).

Macam-MacamDeviden

Berdasarkan bentuk deviden yang dibayarkan, deviden dapat dibedakan atas dua jenis yaitu; deviden tunai (cash dividend) dan deviden saham (stock dividend). Berdasarkan periode satu tahun buku maka deviden dapat dibagi atas dua jenis yaitu; deviden interm dan deviden final.

Teori Kebijakan Deviden

Terdapat beberapa pendapat dan teori yang mengemukakan tentang deviden diantaranya yaitu: Dividend Irrelevance Theory (ketidak relevanan deviden)

Teori yang menyatakan bahwa kebijakan deviden perusahaan tidak mempunyai pengaruh terhadap nilai perusahaan maupun biaya modalnya. Menyimpulkan bahwa nilai perusahaan saat ini tidak dipengaruhi oleh kebijakan deviden.

The Bird in The Hand Theory 
Gordon dan Lintner berpendapat bahwa investor lebih merasa aman untuk memperoleh pendapatan berupa pembayaran deviden dari pada menunggu capital gain.

Tax Preference Theory

Investor menghendaki perusahaan untuk menahan laba setelah pajak dan dipergunakan untuk pembiayaan investasi dari pada deviden dalam bentuk kas. Selain teori diatas terdapat beberapa teori lain mengenai kebijakan deviden yaitu:

1. Teori "Information Content Hypothesis"

Adalah teori yang menyatakan bahwa investor menganggap perubahan deviden sebagai isyarat dari prakiraan manajemen atas laba.

2. Teori "Clientele Effect".

Terdapat banyak kelompok investor dengan berbagai kepentingan, ada investor yang lebih menyukai memperoleh pendapatan saat ini dalam bentuk deviden seperti halnya individu yang sudah pension sehingga investor ini menghendaki perusahaan untuk membayar deviden yang tinggi.

3. Residual Dividend Policy

Kebijakan ini menyatakan perusahaan membayarkan deviden hanya jika terdapat kelebihan dana atas laba perusahaan yang digunakan untuk membiayai proyek yang telah direncanakan.

4. Teori Keagenan (Agency Theory)

Agency Problem biasanya terjadi antara manajer dan pemegang saham atau antara debt holders dan stockholders.

Meskipun konsep tersebut di atas dianggap sebagai teori - teori utama mengenai kebijakan deviden, perkembangan ilmu keangan modern memunculkan pendekatan baru yang lebih relevan dan lebih mampu menjelaskan kebijakan deviden dalam dunia bisnis praktis, yaitu:

Signalling theory is based on the assumption that information is not equally available to all parties at the same time and that information asymmetry is the rule. Information asymmetries can result in very low valuation or a sub optimum investment policy. Signalling theory states that corporate financial decisions are signals sent by the company's managers to investors in order to shake up thewse asymmetries. These signal are the cornerstone of financial communication policy. (www.loreal-finance.com/site/us/contenu/lexique.asp)

Ada kecenderungan harga saham akan naik jika ada pengumuman kenaikan deviden, dan harga saham akan turun jika ada pengumuman penurunan deviden. Tetapi ada argumen lain yang lebih masuk akal yaitu deviden itu senditi tidak mengyebabkan kenaikan (penurnan) harga, tetapi prospek perusahaan, yang di tunjukkan oleh meningkatnya (menurunnya) deviden yang di bayarkan, yang menyebabkan perubahan harga saham. Teori tersebut kemudian di kenal sebagai teori signal atau isi informasi dari deviden (Information Content of Devident). Menurut teori tersebut, deviden mempunyai kandungan informasi yaitu prospek perusahaan di masa mendatang.

Faktor-factor yang Mempengaruhi Kebijakan Deviden

Faktor-faktor yang mempengaruhi rasio pembayaran deviden suatu perusahaan adalah sebagai berikut: (Riyanto,2001)

1. Posisi likuiditas perusahaan.

2. Kebutuhan untuk membayar hutang

3. Tingkat pertumbuhan perusahaan.

4. Pengawasan terhadap perusahaan.

\section{KERANGKA KONSEPTUAL Kerangka Konseptual Penelitian}

Para investor akan melakukan investasi dengan harapan akan mendapatkan keuntungan yang bersifat Dividend atas investasi tersebut.

Pengaruh Current Ratio (CR) terhadap Dividend Payout Ratio. Likuiditas perusahaan merupakan pertimbangan utama dalam kebijakan deviden. Berdasarkan teori dan penelitian terdahulu, dapat diambil 
hipotesis sebagai berikut:

Hipotesis 1: Current Ratio(CR)berpengaruh positifterhadap Dividend Payout Ratio.

Pengaruh collateralizable assets (COL) terhadap Dividend Payout Ratio Darman (2008) mengungkapkan collateralizable assets dianggap sebagai proksi asset asset jaminan untuk baiaya agensi yang terjadi karena konflik antara pemegang saham dan pemegang obligasi. Berdasarkan teori dan penelitian terdahulu, dapat diambil hipotesis sebagai berikut:

Hipotesis 2: collateralizable assets (COL) berpengaruh positif terhadap Dividend Payout Ratio.

Pengaruh Returnon Equity (ROE) terhadap Dividend Payout Ratio Keuntungan perusahaan merupakan factor pertama yang biasanya menjadi pertimbangan Direksi, walaupun untuk membayar deviden perusahaan rugi pun dapat melaksanakannya, karena adanya cadangan dalam bentuk laba, ditahan. Berdasarkan teori dan penelitian terdahulu, dapat diambil hipotesis sebagai.berikut:

Hipotesis 3: Return on Equity (ROE) berpengaruh positif terhadap Dividend Payout Ratio.

Pengaruh Growth terhadap Dividend Payout Ratio Makin cepat tingkat pertumbuhan suatu perusahaan, makin besar kebutuhan dana untuk waktu mendatang untuk membiayai pertumbuhanya. Berdasarkan teori dan penelitian terdahulu, dapat diambil hipotesis sebagai berikut:

Hipotesis 4:Growth berpengaruh negatif terhadap Dividend Payout Ratio.

\section{Hipotesis}

Dari uraian sebelumnya, maka hipotesis dalam penelitian ini adalah:

Hipotesis $1 \quad$ : CR berpengaruh positif terhadap Dividend Payout Ratio.

Hipotesis 2 : COL berpengaruh positif terhadap Dividend Payout Ratio.

Hipotesis 3 : ROE berpengaruh positif terhadap Dividend Payout Ratio.

Hipotesis 4 : Growth berpengaruh negative terhadap Dividend Payout Ratio.

\section{Model Analisis}

Model analisis yang dipakai dalam penelitian ini adalah analisi regresi linier berganda.

Gambar 3.1

Bagan Pengaruh variabel Current Ratio (CR), Collateralizable Assets (COL), Return on Equity (ROE) dan Growth terhadap Dividend Payout Ratio (DPR) pada perusahaan manufaktur yang terdaftar di BEI Indonesia Periode 2005 - 2011

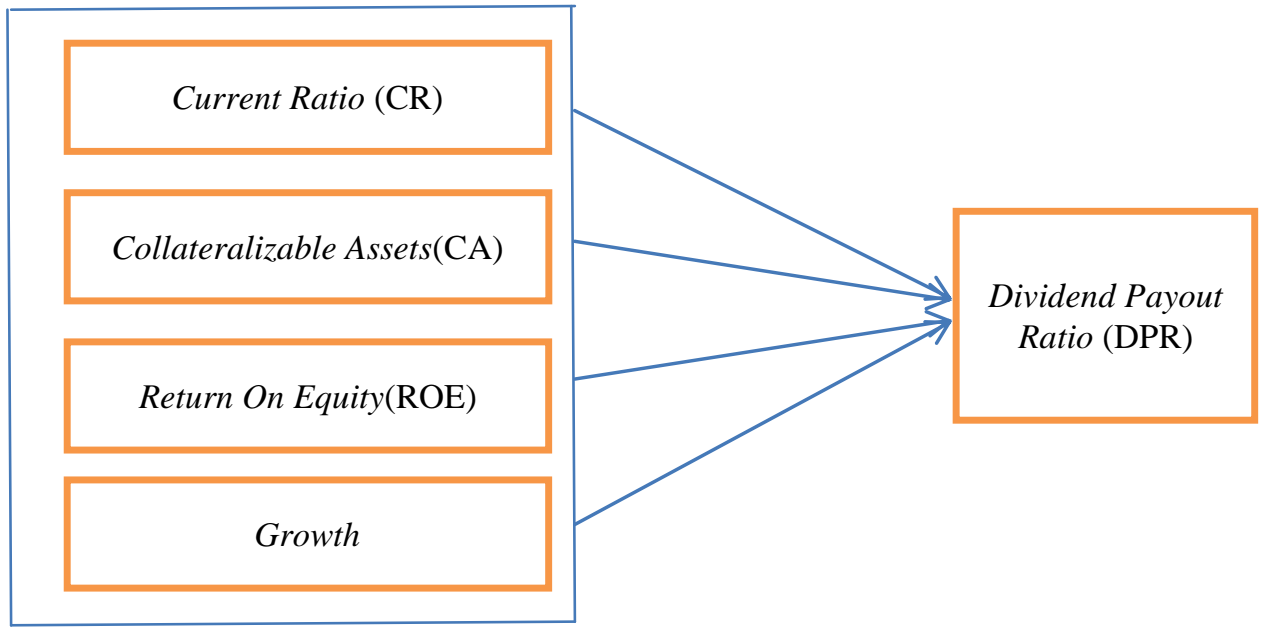




\section{METODE PENELITIAN}

\section{Jenis data dan Sumber Data}

Dalam penelitian ini data yang digunakan adalah data kuantitatif yaitu data laporan keuangan tahunan perusahaan manufaktur periode 2005 - 2011 dengan sampel 8 perusahaan. Sumber data yang di gunakan dalam penelitian ini adalah data sekunder dari lembaga pengumpul data dan kepustakaan terutama data kuantitatif dalam hal ini Bursa Efek Indonesia (BEI)

\section{Populasi, sampel, besar sampel dan teknik pengambilan sampel}

Populasi dalam penelitian ini adalah seluruh perusahaan manufaktur yang terdaftar di Bursa Efek Indonesia dalam periode 2005-2011. Jumlah populasi dalam penelitian ini adalah 190 perusahaan manufaktur. Besar sampel dan teknik pengambilan sampel Perusahaan-perusahaan yang menjadi sampel dalam penelitian ini ditunjukkan pada tabel 2 berikut:

Tabel 2. Data Perusahaan Sampel

\begin{tabular}{|c|l|c|}
\hline NO & \multicolumn{1}{|c|}{ NamaPerusahaan } & Jenis Perusahaan \\
\hline 1. & PT. Fast Food Indonesia, Tbk & Makanan dan Minuman \\
\hline 2. & PT. Multi Bintang Indonesia, Tbk. & Makanan dan Minuman \\
\hline 3. & PT. Gudang Garam, Tbk & Rokok \\
\hline 4. & PT. Colorpak Indonesia, Tbk & Plastik dan pelapis (cat) \\
\hline 5. & PT. Sumi Indo Kabel, Tbk & Otomotif dan Komponen \\
\hline 6. & PT. Metro data Electronics, Tbk & Kosmetik dan barang keperluan RT \\
\hline 7. & PT. Tunas Ridean, Tbk & Logam dan sejenisnya \\
\hline 8. & PT. United Tractor, Tbk & Otomotif dan Komponen \\
\hline \multicolumn{2}{|c}{ Sumber: KSEI dan IDX $2005-2011$} \\
\end{tabular}

\section{Klasifikasi variabel dan definisi operasional variable Klasifikasi Variabel}

Variabel-variabel yang dibutuhkan dalam penelitian ini ada lima variabel yang terdiri dari empat variabel independen yaitu Current Ratio (CR), Collateralizable Assets (COL), Returnon Equity (ROE) dan Growth serta Satu variabel dependen yaitu Dividend Payout Ratio (DPR). Masing-masing variabel penelitian secara operasional dapat didefiniskan sebagai berikut:

\section{Variabel Dependen atau Variabel terikat $\left(r_{1}\right)$}

Variabel terikat adalah variabel yang dipengaruhi oleh variabel bebas. Dalam penelitian ini yang menjadi variabel terikat adalah Devidend Payout Ratio (DPR).

$$
\mathrm{DPR}=\frac{\text { Dividend yer Share }}{\text { Earmine Per Share }}
$$

\section{Variabel Independen atau Variabel bebas}

Variabel bebas adalah variabel yang diduga secara bebas berpengaruh terhadap variabel terikat terdapa tempat variabel bebas dalam penelitian ini yaitu:

1. Currentratio/ CR (X1) Likuiditas perusahaan ditunjukkan oleh besar kecilnya aktiva lancarya itu aktiva yang mudah untuk diubah menjadi kas. Secara sistematis CR dapat dirumuskan sebagai berikut: (Sartono,2001)

$$
\mathrm{CR}=\frac{\text { aktiva lancar }}{\text { utang lancar }}
$$

2. CollateralizableAssets/COL (X2)

Collateral Assets adalah asset perusahaan yang dapat digunakan sebagai jaminan peminjaman.

$$
\mathrm{COL}=\frac{\text { whlive lelup }}{\text { Toral aktiva }}
$$




\section{ReturnonEquity/ $\mathrm{ROE}(\mathrm{X} 3)$}

Merupakan rasio untuk mengukur kemampuan perusahaan dalam menghasilkan laba dengan memanfaatkan modal sendiri yang dimilikinya.

$$
\mathrm{ROE}=\frac{\text { Lababersint }}{\text { Total akutus }}
$$

4. $\operatorname{Growth}(\mathrm{X} 4)$

Growth menunjukkan pertumbuhan assets dimana asset merupakan aktiva yang digunakan untuk aktivitas operasional perusahaan.

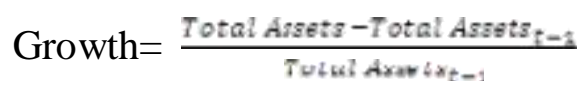

\section{Uji Hipotesis}

Pengujian hipotesis dilakukan dengan menggunakan model analisis regresi berganda bertujuan untuk memprediksi berapa besar kekuatan pengaruh variabel independen terhadap variabel dependen. Persamaan regresinya adalah :

$$
\begin{aligned}
& \mathrm{Y}=\alpha+\beta_{1} \mathrm{X}_{1}+\beta_{2} \mathrm{X}_{2}+\beta_{3} \mathrm{X}_{3}+\beta_{4} \mathrm{X}_{4}+\mathrm{e} \\
& \text { dimana: } \\
& \mathrm{Y}=\text { Dividend payout ratio } \\
& \alpha=\text { Konstanta } \\
& \beta=\text { Koefisien regresi } \\
& \mathrm{X} 1=\text { Current Ratio } \\
& \mathrm{X} 2=\text { Collateralizable assets } \\
& \mathrm{X} 3=\text { Return on Equity } \\
& \mathrm{X} 4=\text { Growth } \\
& \mathrm{E}=\text { error }
\end{aligned}
$$

Sementara itu, langkah-langkah untuk menguji pengaruh variabel independen yaitu Current ratio, collateralizable assets, return on equity, dan growth dilakukan dengan uji simultan dan uji parsial.

\section{Uji Simultan (Uji F)}

Uji F digunakan untuk mengetahui ada tidaknya pengaruh bersama-sama antara variabel-variabel independen terhadap variabel dependen. Kriteria pengujian yang digunakan adalah jika probability value ( $p$ value $)<0,05$, maka Ha diterima dan jika $p$ value $>0,05$, maka Ha ditolak.

Uji F dapat pula dilakukan dengan membandingkan nilai Fhitung dan Ftabel. Jika Fhitung > F tabel (n-k-1), maka Ha diterima.Artinya, secara statistik data yang ada dapat membuktikan bahwa semua variabel independen $(\mathrm{X} 1, \mathrm{X} 2, \mathrm{X} 3)$ berpengaruh terhadap variabel dependen (Y). Jika Fhitung < F tabel (n-k-1), maka Ha ditolak. Artinya, secara statistik data yang ada dapat membuktikan bahwa semua variabel independen $(\mathrm{X} 1, \mathrm{X} 2, \mathrm{X} 3)$ tidak berpengaruh terhadap variabel dependen $(\mathrm{Y})$.

\section{Uji Parsial (Uji t)}

Uji t digunakan untuk mengetahui pengaruh masing-masing variabel independen terhadap variabel dependen. Adapun dasar pengambilan keputusan mengenai penerimaan dan penolakan hipotesis dalam penelitian ini adalah:
1. Jika $t_{\text {hitung }}>t_{\text {tabel }}$, maka Hipotesis diterima
2. Jika $\mathrm{t}_{\text {hitung }}<\mathrm{t}_{\text {table }}$, maka Hipotesis ditolak
3. Jika signifikansi $>0,05$ maka Hipotesis ditolak
4. Jika signifikansi $<0,05$ maka Hipotesis diterima

\section{Melakukan interpretasi model regresi linier berganda}

Berdasarkan persamaan regresiberikut dilakukan interpretasi :

$$
\mathbf{Y}=\alpha+\boldsymbol{\beta}_{1} \mathbf{X}_{1}+\boldsymbol{\beta}_{2} \mathbf{X}_{2}+\boldsymbol{\beta}_{3} \mathbf{X}_{3}+\boldsymbol{\beta}_{4} \mathbf{X}_{4}+\varepsilon
$$

a: Konstanta yang menyatakan bahwa jika tidak ada variabel current ratio (CR), collateralizable asset (CA), return on equity (ROE), dan growth maka Dividend Payout Ratio (DPR) adalah sebesar 1 satuan. 
$\beta_{1}$ : Koefisien yang menyatakan bahwa setiap kenaikan atau penurunan 1 kali pada current ratio (CR), maka akan menambah atau mengurangi Dividend Payout Ratio(DPR) pada perusahaan manufaktur di BEI sebesar $\beta_{1}$.

$\beta_{2}$ : Koefisien yang menyatakan bahwa setiap kenaikan atau penurunan 1 kali pada collateralizable asset (CA), maka akan menambah atau mengurangi Dividend Payout Ratio (DPR) pada perusahaan manufaktur di BEI sebesar $\beta_{2}$.

$\beta 3$ : Koefisien yang menyatakan bahwa setiap kenaikan atau penurunan 1 kali pada return on equity (ROE), maka akan menambah atau mengurangi Dividend Payout Ratio (DPR) pada perusahaan manufaktur di BEI sebesar $\beta_{3}$.

$\beta_{4}$ : Koefisien yang menyatakan bahwa setiap kenaikan atau penurunan 1 kali pada growth, maka akan menambah atau mengurangi Dividend Payout Ratio (DPR) pada perusahaan manufaktur di BEI sebesar $\beta 4$.

$\varepsilon$ : $\quad$ Error term

\section{HASIL PENELITIAN DAN PEMBAHASAN \\ Hasil Penelitian \\ Hasil Statistik Deskriptif}

Hasil statistik deskriptif dari masing-masing variabel yaitu current ratio, collateralizable assets, return on equity, growth dan dividend payout ratio di sajikan dalam tabel 5.1 sebagai berikut :

1. Rata - rata dividend payout ratio perusahaan (dengan jumlah data 56) adalah sebesar 38,4863 dengan standard deviasi 27,94233

2. Rata - rata current ratio perusahaan (dengan jumlah data 56) adalah sebesar 180,4509 dengan standard deviasi 127,01514

3. Rata - rata collateralizable assets perusahaan (dengan jumlah data 56) adalah sebesar 26,3214 dengan standard deviasi 18,07269

4. Rata - rata return on equity perusahaan (dengan jumlah data 56) adalah sebesar 26,8239 dengan standard deviasi 44,92210

5. Rata - rata growth perusahaan (dengan jumlah data 56) adalah sebesar 30,1963 dengan standard deviasi 30,30308

\section{Analisis data}

\section{Menentukan variabel independen dan dependen}

Dalam pengujian ini terdapat variabel independen dan variabel dependen, sebagai berikut :

Variabel Independen (X) yaitu:

$$
\begin{aligned}
& \mathrm{X} 1=\text { Current ratio } \\
& \mathrm{X} 2=\text { Collateralizable assets } \\
& \mathrm{X} 3=\text { Return on equity } \\
& \mathrm{X} 4=\text { Growth }
\end{aligned}
$$

Variabel dependen (Y) yaitu dividend payout ratio

\section{Melakukan Pengujian Hipotesis \\ Uji Simultan (uji F)}

Dari hasil perhitungan pengujian yang di lakukan (Uji F) dapat dilihat variabel independen yang tidak berpengaruh terhadap variabel dependen. Hal ini didasarkan pada perbandingan Fhitung dengan Ftabel dan signifikansi hitung berada di angka 0,05. Berdasarkan hasil pengujian statistik Uji simultan (Uji F) Fhitung diperoleh angka 0,774 < dari Ftabel 2,55 dan sig. hitung 0,547> $>$; 5\% (0,05). Hal ini berarti bahwa Current ratio(CR), collateralizable asset(CA), return on equity(ROE), dan growth secara bersama-sama (simultan) tidak berpengaruh terhadap variabel dependen yaitu dividend payout ratio (DPR).

\section{Uji Statistik (uji t)}

Dari hasil perhitungan pengujian yang dilakukan (uji t) dapat dilihat variabel independen secara parsial yaitu current ratio (X1), collateralizable asset (X2), return on equity (X3), dan growth (X4) tidak berpengaruh terhadap variabel dependen yaitu dividend payout ratio (Y). Berdasarkan hasil 
perbandingan $t$ hitung dengan $t$ tabel dan sig. hitung dengan $\alpha$ : 5\% (0.05). Hal ini ditunjukkan berdasarkan:

1. Hasil uji statistik Current ratio(X1) berdasarkan t hitungdiperoleh angka $-0,834<$ dari t tabel 1,67528 dengan sig. hitung $0,408>\alpha: 5 \%(0,05)$ jadi H1 ditolak, artinya Current ratio(X1) tidak berpengaruh positif terhadap dividend payout ratio $(\mathrm{Y})$.

2. Hasil uji statistik collateralizable asset (X2) berdasarkan $\mathrm{t}$ hitungdiperoleh angka $-0,403<$ dari $\mathrm{t}$ tabel 1,67528 dengan sig. hitung 0,264 > $\alpha$ : 5\% $(0,05)$ jadi $\mathrm{H} 2$ ditolak, artinya collateralizable asset $(\mathrm{X} 2)$ tidak berpengaruh positif terhadap dividend payout ratio $(\mathrm{Y})$.

3. Hasil uji statistik return on equity (X3) berdasarkan t hitungdiperoleh angka $1,128<$ dari t tabel 1,67528 dengan sig. hitung $0,734>\alpha: 5 \%(0,05)$ jadi $\mathrm{H} 3$ ditolak, artinya return on equity $(\mathrm{X} 3)$ tidak berpengaruh positif terhadap dividend payout ratio $(\mathrm{Y})$.

4. Hasil uji statistik growth (X4) berdasarkan t hitungdiperoleh angka $0,342<$ dari t tabel 1,67528 dengan sig. hitung $0,408>\alpha: 5 \%(0,05)$ jadi $\mathrm{H} 1$ ditolak, artinya growth $(\mathrm{X} 4)$ tidak berpengaruh negative terhadap dividend payout ratio $(\mathrm{Y})$.

Jadi hasil kesimpulan hipotesis dari variabel current ratio (X1), collateralizable asset (X2), return on equity (X3), secara parsial tidak berpengaruh positif terhadap dividend payout ratio (DPR) dan growth (X4) secara parsial tidak berpengaruh negative terhadap variabel dependen yaitu dividend payout ratio $(\mathrm{Y})$.

\section{Menentukan besarnya koefisien determinasi ( $\mathbf{R}$ Square/ $\left.\mathbf{R}^{\mathbf{2}}\right)$}

Angka R Square yaitu 0,057 merupakan angka pengkuadratan dari koefisien atau $(0,239)^{2}=0,057$. R Square biasa disebut dengan koefisien determinasi, angka tersebut berarti 5,7\% Dividend payout ratio dapat dijelaskan variabel current ratio $(\mathrm{CR})$, collateralizable asset $(\mathrm{CA})$, return on equity (ROE), dan growth. Sedangkan sisanya $(100 \%-5,7 \%=94,3 \%)$ disebabkan oleh faktor - faktor lain. Faktor - faktor lain yang dimaksud antara lain adalah debt to equity ratio (DER), earning per share (EPS), return on assets (ROA) serta kemampuan manajemen untuk dapat memberikan informasi yang bernilai dalam pengambilan keputusan untuk membagikan deviden dan lain sebagainya.

\section{Melakukan Interpretasi model Regresi linier berganda}

Interpretasi model regresi linier berganda seperti yang disajikan pada tabel 5.5 sehingga dapat dituliskan persamaan regresinya sebagai berikut:

$$
\mathrm{Y}=41,726-0,027 \mathrm{X} 1-0,087 \mathrm{X} 2+0,100 \times 3+0,044 \times 4
$$

Persamaan diatas berarti,

Nilai konstan $(a)=41,726$. Nilai ini menunjukkan bahwa apabila tidak ada variabel current ratio (X1), collateralizable asset (X2), return on equity (X3), dan growth (X4) maka devidend payout ratio (DPR) akan naik sebesar 41,726 kali. Dengan kata lain devidend payout ratio akan naik sebesar 41,726 sebelum atau tanpa adanya variabel current ratio (CR), collateralizable asset (CA), return on equity (ROE), dan growth (X1,X2,X3, dan X4 =0)

Nilai current ratio $(\mathrm{X} 1)(\mathrm{b} 1)=-0,027$. Nilai parameter atau koefisien regresi b1 ini menunjukkan bahwa setiap variabel current ratio (CR)meningkat 1 kali, maka Deviden payout ratio(DPR) akan turun sebesar -0,027 kali. Dengan kata lain setiap penurunan Deviden payout ratio(DPR) dibutuhkan variabel current ratio $(\mathrm{CR})$ sebesar $-0,027$ dengan asumsi variabel lain tetap (X2, X3) dan $\mathrm{X} 4)$ atau ceteris paribus.

Nilai collateralizable asset (X2) (b2) $=-0,087$. Nilai parameter atau koefisien regresi b2 ini menunjukkan bahwa setiap variabel collateralizable asset meningkat 1 kali, maka Deviden payout ratio(DPR) akan turun sebesar -0,087 kali. Dengan kata lain setiap penurunan Deviden payout ratio(DPR) dibutuhkan variabel collateralizable asset (CA) sebesar -0,087 dengan asumsi variabel lain tetap (X1, X3, dan X4) atau ceteris paribus.

Nilai return on equity (X3) (b3) $=0,100$. Nilai parameter atau koefisien regresi b3 ini menunjukkan bahwa setiap variabel return on equity (ROE) meningkat 1 kali, maka Deviden payout ratio(DPR)akan naik sebesar 0,100 kali. Dengan kata lain setiap kenaikan Deviden payout ratio(DPR) dibutuhkan variabel return on equity (ROE) sebesar 0,100 dengan asumsi variabel lain tetap (X1, X2, dan X4) atau ceteris paribus. 
Nilai growth $(\mathrm{X} 4)(\mathrm{b} 4)=0,044$. Nilai parameter atau koefisien regresi b4 ini menunjukkan bahwa setiap variabel growthmeningkat 1 kali, maka Deviden payout ratio(DPR)akan naik sebesar 0,044 kali. Dengan kata lain setiap kenaikkan Deviden payout ratio(DPR) dibutuhkan variabel growth sebesar 0,044 dengan asumsi variabel lain tetap (X1, X2, dan X3) atau ceteris paribus.

\section{Pembahasan}

\section{Pembahasan Hipotesis 1}

Hipotesis pertama yang diajukan menyatakan bahwa current ratio (CR) berpengaruh positif terhadap dividend payout ratio (DPR). Dari hasil penelitian diperoleh koefisien regresi untuk variable current ratio (CR) sebesar -0,027 dengan nilai signifikansi sebesar 0,408, dimana nilai ini tidak signifikan pada tingkat signifikansi 0,05 karena lebih besar dari 0,05. Dengan demikian hipotesis pertama yang menyatakan bahwa current ratio (CR) berpengaruh positif terhadap dividend payout ratio (DPR) tidak dapat diterima atau $\mathrm{H} 1$ ditolak.

Hasil penelitian ini menunjukkan bahwa current ratio (CR) tidak berpengaruh positif terhadap dividend payout ratio (DPR). Hasil penelitian ini menunjukkan bahwa informasi current ratio (CR) yang sebagaimana biasa diperoleh dari laporan keuangan tidak berpengaruh positif signifikan pada keputusan pembagian deviden kepada para investor pada perusahaan manufaktur yang terdaftar di bursa efek Indonesia. Posisi kas atau likuiditas perusahaan merupakan faktor yang penting yang harus dipertimbangkan sebelum mengambil keputusan untuk menetapkan besarnya deviden yang akan dibayarkan kepada para pemegang saham. Akan tetapi perusahaan yang sedang tumbuh secara rendabel (perusahaan yang masih mencari keuntungan), mungkin tidak begitu kuat posisi likuiditasnya karena sebagian besar dari dananya tertanam dalam aktiva tetap dan modal kerja sehingga kemampuannya untuk membayar deviden pun sangat terbatas. Di satu sisi deviden tunai dapat dibagikan hanya dengan uang kas. Apabila likuiditas tersebut tertahan pada aktiva yang sifatnya tidak likuid maka dengan sendirinya deviden tidak dapat di bagikan. Keputusan para pemegang saham dalam Rapat Umum Pemegang Saham pun mempengaruhi kebijakan dalam pembagian deviden.

Hasil temuan ini mendukung hasil penelitian dari Kania dan Bacon (2005), Michell Suharli (2007), Handayani (2010), dan Murhadi (2010) dimana hasil penelitiannya menunjukkan bahwa current ratio (CR) tidak memiliki pengaruh positif signifikan terhadap dividend payout ratio (DPR).

\section{Pembahasan Hipotesis 2}

Hipotesis kedua yang diajukan menyatakan bahwa collateralizable assets (COL) berpengaruh positif terhadap dividend payout ratio (DPR). Dari hasil penelitian diperoleh koefisien regresi untuk variable collateralizable asset (COL) sebesar -0,087 dengan nilai signifikansi sebesar 0,689, dimana nilai ini tidak signifikan pada tingkat signifikansi 0,05 karena lebih besar dari 0,05. Dengan demikian hipotesis kedua yang menyatakan bahwa collateraliable assets (COL) berpengaruh positif terhadap dividend payout ratio (DPR) tidak dapat diterima atau $\mathrm{H} 2$ ditolak.

Hasil penelitian ini berarti bahwa nilai colllateralizable asset (COL) tidak berpengaruh pada dividend payout ratio (DPR). Hasil penelitian yang tidak berpengaruh antara variable collateralizable asset (COL) terhadap dividend payout ratio (DPR) disebabkan adanya permintaan jaminan oleh pihak kreditor berupa aktiva kepada pemegang saham pada saat membutuhkan pendanaan. Semakin rendahnya collateralizable asset (COL) yang dimiliki perusahaan akan meningkatkan konflik kepentingan antara pemegang saham dan kreditor sehingga kreditor akan menghalangi perusahaan untuk membayar deviden dengan jumlah besar kepada pemegang saham karena takut piutang mereka tidak terbayar. Hal ini mengindikasikan bahwa collateralizable assets (COL) yang menurun menandakan pembagian deviden akan menurun bahkan tidak membagikan deviden sama sekali. Akibatnya tidak adanya pengaruh antara collateralizable asset (CA) terhadap dividend payout ratio (DPR).

Hasil temuan ini tidak mendukung hasil penelitian dari Nugraha (2006) dan Wahyudi dan Baidori (2008) yang menunjukkan bahwa terdapat pengaruh positif signifikan antara collateralizable asset (CA) terhadap deviden payout ratio (DPR). Hal ini berarti tingginya jaminan yang dimiliki perusahaan akan mengurangi konflik kepentingan antara pemegang saham dengan kreditor sehingga perusahaan dapat membayar deviden dengan jumlah yang lebih besar. 


\section{Pembahasan Hipotesis 3}

Hipotesis ketiga yang diajukan menyatakan bahwa return on equity (ROE) berpengaruh positif terhadap dividend payout ratio (DPR). Dari hasil penelitian diperoleh koefisien regresi untuk variable return on equity (ROE) sebesar 0,100 dengan nilai signifikansi sebesar 0,264 , dimana nilai ini tidak signifikan pada tingkat signifikansi 0,05 karena lebih besar dari 0,05. Dengan demikian hipotesis ketiga yang menyatakan bahwa return on equity (ROE) berpengaruh positif terhadap dividend payout ratio (DPR) tidak dapat diterima atau H3 ditolak.

Hasil penelitian ini menunjukkan bahwa return on equity (ROE)tidak berpengaruh positif terhadap deviden payout ratio (DPR). Hasil penelitian ini menunjukkan bahwa informasi return on equity (ROE) yang berarti kemampuan perusahaan menghasilkan laba yang tersedia bagi pemegang saham perusahaan belum bisa memberikan pengaruh signifikan terhadap deviden payout ratio (DPR). Deviden merupakan sebagian dari laba bersih yang diperoleh perusahaan, oleh karenanya deviden akan dibagikan, jika perusahaan memperoleh keuntungan. Keuntungan yang layak dibagikan kepada para pemegang saham adalah keuntungan setelah perusahaan memenuhi seluruh kewajiban tetapnya yaitu beban bunga dan pajak. Investor menghendaki perusahaan untuk menahan laba setelah pajak dan dipergunakan untuk pembiayaan investasi daripada deviden dalam bentuk kas. Besar kecilnya keuntungan dari perusahaan berpengaruh terhadap hasil return on equity (ROE) yang darinya deviden dibagikan.

Hasil temuan ini tidak mendukung hasil penelitian dari Kania dan Bacon (2005) dan Michell Suharli (2006) dimana hasil penelitiannya menunjukkan bahwa return on equity (ROE) memiliki pengaruh positif signifikan terhadap dividend payout ratio (DPR). Kecilnya keuntungan yang di peroleh oleh perusahaan setelah memenuhi seluruh kewajiban tetapnya akan sangat mempengaruhi besar kecilnya dividend payout ratio (DPR) yang akan dibagikan kepada pemegang saham. Hal ini berarti naiknya keuntungan perusahaan akan sangat mempengaruhi nilai deviden yang akan di bagikan kepada para investor atau pemegang saham.

\section{Pembahasan Hipotesis 4}

Hipotesis keempat yang diajukan menyatakan bahwa growth berpengaruh negatif terhadap dividend payout ratio (DPR). Dari hasil penelitian diperoleh koefisien regresi untuk variable growth sebesar 0,044 dengan nilai signifikansi sebesar 0,734, dimana nilai ini tidak signifikan pada tingkat signifikansi 0,05 karena lebih besar dari 0,05. Dengan demikian hipotesis keempat yang menyatakan bahwa growth berpengaruh negatif terhadap dividend payout ratio (DPR) tidak dapat diterima atau H4 ditolak.

Makin cepat tingkat pertumbuhan suatu perusahaan, makin besar kebutuhan dana untuk waktu mendatang untuk membiayai pertumbuhannya. Perusahaan tersebut biasanya akan lebih senang menahan pendapatannya daripada dibayarkan sebagai deviden,

Hasil penelitian ini menunjukkan kondisi yang sesuai dengan teori yang mendasarinya yaitu apabila perusahaan telah mencapai tingkat pertumbuhan sedemikian rupa sehingga perusahaan telah mencapai tingkat pertumbuhan yang mapan, dimana kebutuhan dananya dapat dipenuhi dengan dana yang berasal dari pasar modal atau sumber dana ekstern lainnya, maka keadaannya adalah perusahaan dapat menetapkan dividend payout ratio (DPR) yang tinggi.

Hasil ini menunjukkan bahwa tingkat pertumbuhan perusahaan berpengaruh positif terhadap dividend payout ratio (DPR). Sejalan dengan penelitian ini hasil penelitian oleh Nugroho (2004) juga menemukan bahwa growth berpengaruh positif signifikan terhadap dividend payout ratio (DPR). Hal ini mengindikasikan bahwa investor masih menggunakan rasio growth dalam mengambil keputusan dalam hal menentukan nilai pembagian deviden atau dividend payout ratio (DPR) terhadap para pemegang saham.

\section{KESIMPULAN DAN SARAN}

\section{Kesimpulan}

Berdasarkan uji statistik yang telah dilakukan, hasil yang diperoleh adalah sebagai berikut:

1. Current ratio (X1) tidak berpengaruh positif terhadap Dividend Payout Ratio (Y) pada perusahaan manufaktur di BEI.

2. Collateralizable asset(X2) tidak berpengaruh positif terhadap Dividend Payout Ratio (Y) pada 
perusahaan manufaktur di BEI.

3. Return on equity(X3) tidak berpengaruh positif terhadap Dividend Payout Ratio (Y) pada perusahaan manufaktur di BEI.

4. Growth $(\mathrm{X} 4)$ tidak berpengaruh negatif terhadap Dividend Payout Ratio (Y) pada perusahaan manufaktur di BEI.

\section{Saran}

1. Penelitian ini hanya menggunakan sampel penelitian yangberasal dari perusahaan manufaktur sehingga belum tentu dapat digeneralisasi pada jenis industry lainnya. Hal ini disebabkan karena terbatasnya waktu penelitian. Disarankan pada penelitian selanjutnya ruang lingkup penelitian dapat diperluas kejenis-jenis industry lainnya juga menambahkan variabel penelitian seperti Debt to Equity Ratio (DER), Return on Equity (ROE), dan rasio - rasio yang lain. Dan juga diharapkan pada penelitian selanjutnya untuk menambahkan rentang waktu yang lebih panjang.

2. Bagi investor dan kreditor, pengambilan keputusan yang baik dan tepat dalam hal pembagian deviden untuk suatu perusahaan perlu analisis yang baik dalam hal analisis fundamental dan teknikal.

\section{DAFTAR PUSTAKA}

Agnes Sawir. 2005. Analisis Kinerja Keuangan dan Perencanaan Keuangan Perusahaan, Gramedia Pustaka Utama,Jakarta.

Agus Sartono, 2001. Manajemen Keuangan Teori dan Aplikasi. Yogyakarta: BPEF-YOGYAKARTA

Ambarwati, SriDwi Ari.2010.Manajemen Keuangan Lanjut. Graha Ilmu. Amidu,

Andriyani Pujiastuti, Maria.2008.“Analisis Pengaruh Cash Ratio, Debt to Equity Ratio, Insider Ownership, Invesment Opportunity Set (IOS), dan Profitability terhadap Kebijakan Dividen” Tesis. Program PascaSarjanaUniversitas DiponegoroSemarang.

Ang, Robbert. 1997. Buku Pintar Pasar Modal Indonesia, Edisi 1, Mediasoft Indonesia.

Anil, Kand Kapoor, S. 2008. "Determinant of Dividend Payout Ratio-A Study of Indian Information Technology Sector". International Research Journal of Financeand Economics. p.63-71.

Chasanah, Amalia Nur. 2008. "Faktor-faktor yang Mempengaruhi Dividend Payout Ratio pada Perusahaan yang Listed di Bursa Efek Indonesia (Perbandingan pada Perusahaan yang Sebagian Sahamnya Dimiliki oleh manajemen dan yang Tidak Dimiliki Oleh Manajemen" Tesis. Program Pasca Sarjana Universitas Diponegoro Semarang.

Crutchley, C, and Hansen, R. 1989. A Test of the Agency Theory of Managerial Ownership, Corporate Leverage, and Corporate Dividends. Financial Management, Winter 1989, 36-46.

Damayanti, S dan Achyani, F (2006). Analisis Pengaruh Investasi, Likuiditas, Profitabilitas, Pertumbuhan Perusahaan, dan Ukuran Perusahaan terhadap Kebijakan Dividen Payout Ratio. Jurnal Akuntansi dan Keuangan Vol. 5 No.1 April. p. 51-62.

Elloumi, Fathi dan Jena-Pierre Gueyle. 2003. "CEO Compensation, IOS, and The Role of Corporate Governance, ”Corporate Governance,Vol.1, No.2, p.23-33

Ismiyanti, Fitri dan Mamduh Hanafi. 2003. Kepemilikan Manajerial, Kepemilikan Institutional, Risiko, Kebijakan Hutang dan Kebijakan Dividen: Analisa Persamaan Simultan, "Makalah Seminar, Simposium Nasional Akuntansi VI, Ikatan Akuntansi Indonesia, 260-276.

Gaver, J J dan Keneth M Gaver. 1993. "Additional Evidenceon The Association Between The Investment Opportunity Set and Corporate Financing, Dividend andCompensation Policies, Journal of Accounting and economics, Vol.1,p.233-265

Gill, Amarjit, Nahum Biger, dan Rajendra Tibrewala. 2010. "Determinants of Dividend Payout Ratios: Evidence for United States. The Open Business Journal, 2010,3,8-14.

Gitman, Lawrence J. 2003, Principles of Managerial Finance, Edisi Kesepuluh, Addison Wesley Publishing Company, Massachusetts.

Hafeez, Ahmed dan Attiya Y. Javid. 2009. "The Determinants of Dividend Policyin Pakistan". International Research Journal of Finance and Economics. ISSN1450-2887 Issue29 (2009). Euro Journals Publishing, Inc. 2009. 